\title{
Presenting Strategies for Promoting Security and Safety in High-Rise Building against Fire (In the Greater Tehran)
}

\author{
Mostafa Adelizadeh \\ Phd Student of Environment \\ Managegment \\ Department of Environmental \\ Education \\ Islamic Azad University, \\ Roodehen Branch, Tehran, \\ Iran
}

\author{
Nahid Rezaii \\ Department of Engineering \\ Faculty of Engineering \\ Engineering Institue of higher \\ Education, Saveh, Iran
}

\author{
Hamed Mobaraki Sohrabi \\ Department of Engineering \\ Faculty of Engineering \\ Engineering Institue of higher \\ Education, Saveh, Iran
}

\begin{abstract}
This study has been done in Tehran with the purpose of presenting strategy for promoting security and safety in highrise buildings against fire. From the point of view on categorizing researches based on purpose, this one is an applied research, and from viewpoint on collecting data is descriptive-survey one; also in the all types of descriptive research methods, it is a case study. Our statistical population was comprised of 26 senior managers in Health, Safety and Environment (HSE) that expert questionnaire released between them. Based on studies, the main criteria of this research are building structural engineering, fire alarm systems and firefighting, safety design in building, and the occupants' behavioral skills, that and each of them included some sub-criteria. Analyzing the data was accomplished by applying the analytic hierarchy process (AHP) approach. Generally, it is proved that the criterion "occupants' behavioral skills" with normalized weight $0 / 553$ has the most priority, and the other hand the sub-criteria of "pumps and fire station installations with normalized weight 0/553 is the most important priority in sub-criteria.
\end{abstract}

Keywords

Safety, High-Rise Buildings, Fire, AHP

\section{INTRODUCTION}

The emergence of basic evolution in works and lifestyle, the requirement for large buildings and industrial plants, the development of energy contribution and gas pipelines, applying the various equipment, the widespread use of flammable materials, the expansion in buildings size, and much more other elements all increased the rate of fire in buildings and put them at risk.

Fire was always one of the most incidents that caused much damage to the property and human itself; the rate of fire occurred during April to July 2016 in Tehran according to the report by Tehran Fire Department has presented in Table 1.

Repeatedly occurrence of fire in high-rise buildings and the residential towers requires that the responsibility of safety and preventing incidents and fires, and then keep safe occupants, owners and their properties be taken by experienced and efficient persons, as well giving necessary trainings and instructions to occupants, identifying probable risks and making suitable coordination with related authorities to be resolved. The importance of this point is more and more increasing related to the number of occupants and owners in any high-rise buildings, and in residential apartment complex requires to be considered more carefully .
In a study by Juan Chen, Jian Ma, S. M. Lo (2017) [1] the 'event-driven modeling of elevator assisted evacuation in ultra high-rise buildings' has been studied, and the importance of elevators on occupants' evacuation have been reviewed. "The collapse of World Trade Center in the 9/11 event makes people reconsider ultra high-rise building evacuation strategies. Of the current strategies, using elevators in ultra high-rise buildings to assist evacuation seems to be promising in improving evacuation efficiency. To quantitatively evaluate elevator assisted evacuation process, an event-driven agent-based modeling approach is proposed in the present paper. This modeling approach could capture not only the movement characteristics of stair-using occupants but also the detailed elevator motion features."

Sharma et al. (2014) [2] in a study "evacuation patterns in high-rise buildings" reviewed. "Buildings are built for function, beauty, fame, profit, commemoration, fun, economy and the hierarchy of motivation depending on the owner or developer. Safety has not been generally considered a critical factor. The paper will discuss strategies implemented for ensuring safety of occupants in tall buildings under fire conditions. The life safety strategy must integrate key fire safety systems with building features. The possible use of vertical transportation for phased evacuation requires a combination of safe havens, innovative smoke management and sophisticated communication systems to ensure occupants under threat from fire are moved to safe locations within the building".

Koo et al. (2013) [3]in comparative study of evacuation strategies for people with disabilities in high-rise building, for a heterogeneous population in high-rise building environments and comparison with traditional simultaneous evacuation strategy have reviewed. The simulation results for a 24-story building as follows:

"We found that a vertically phased evacuation strategy that varies delay times by physical location is not useful for the simulated building. Second, a phased evacuation strategy that applies a fixed evacuation delay to residents with wheelchairs reduces the aggregated evacuation times, but delaying evacuations of a specific group of individuals may not be ethical or accepted. Finally, evacuation strategies that allows residents with wheelchairs to use elevators are effective, suggesting that emergency administrators should assess whether elevators in their buildings are appropriate for evacuation purposes with appropriate electric controls, electric power, and fire and smoke protection. 
Fang et al. (2012) [4]in an experimental study on evacuation process in stairwells of high-rise buildings by means of experiment or modeling have reviewed. "In this study, an evacuation experiment was conducted in a stairwell of an 8layer high-rise building. The evacuation process in the stairwell was recorded by video cameras. Some typical movement characteristics and parameters were extracted based on the recording data. The results demonstrate that the downward velocity is determined by three aspects: merging behavior in the entrance buffer of the stairwell, strength of participants and visibility in the stairwell.".
Black et al. (2009) [5] studied that "smoke movement in elevator shafts in the event of fire, smoke often travels long distances from the fire floor, and in the particular case of a high-rise fire, smoke frequently moves to upper floors via open passages such as elevator shafts and stairwells. The results are used to recommend construction practices and the operation of floor pressurization equipment that will diminish the volume of smoke delivered to upper floors in a high-rise building".

Table 1. The statistics1 of fire in Tehran during 3 months, April to July 2016

\begin{tabular}{|c|c|c|c|c|c|}
\hline $\begin{array}{c}\text { Type of } \\
\text { incident }\end{array}$ & $\begin{array}{c}\text { Type of } \\
\text { structural } \\
\text { materials }\end{array}$ & Number of floors & cause & Damage (IRR) & $\begin{array}{c}\text { Type of } \\
\text { incident }\end{array}$ \\
\hline C1 & fire & $\begin{array}{c}\text { Steel frame structure with brick } \\
\text { ceiling }\end{array}$ & 7 & $\begin{array}{c}\text { Carelessness, negligence, an } \\
\text { overload from electrical system }\end{array}$ & $40,000,000$ \\
\hline C2 & fire & $\begin{array}{c}\text { Concrete structure with ceiling } \\
\text { built from concrete, beam with } \\
\text { clay }\end{array}$ & 6 & $\begin{array}{c}\text { Unawareness, unaware of } \\
\text { leaking flammable gases }\end{array}$ & $150,000,000$ \\
\hline C3 & fire & Steel frame, iron beam & 6 & $\begin{array}{c}\text { Negligence, carelessness in } \\
\text { electrical connector }\end{array}$ & $2,060,100,000$ \\
\hline f4 & $\begin{array}{c}\text { Steel frame structure with ceiling } \\
\text { built from concrete, beam with } \\
\text { clay }\end{array}$ & 9 & Negligence, carelessly & $20,000,000$ \\
\hline
\end{tabular}

Luo \& Wong (2006) [6]in a survey "the evacuation strategy for super high-rise buildings" have studied. "High-rise buildings are always a major concern to the life safety of occupants due to the elevated height and extended vertical travel distance for the egress and means of access. The fire safety challenges of super high-rise and high-rise buildings have been discussed and found that most of the challenges are related to the evacuation component. The existing evacuation strategies for high-rise buildings, i.e. total evacuation, phased evacuation and stay-in-place approach, have been discussed in detail. In order to address the feasibility to increase the total building evacuation efficiency of super high-rise buildings, a lift evacuation strategy has been discussed in this paper. As an example, the evacuation for a super high-rise building with lifts has been studied. The traditional total building evacuation using stairs and the proposed lift evacuation strategy have been simulated using 3-D evacuation software to demonstrate the evacuation efficiency. The results showed that the total building evacuation time could be shortened significantly. This lift evacuation strategy can be regarded as an enhancement to the evacuation safety of super high-rise buildings in case of extreme emergency without significant changes to the traditional evacuation strategy and additional investment in safety provisions.

Chow (2006) [7]in research with the subject "fire safety provisions for super-tall buildings" has reviewed. In this paper, protecting of high-rise buildings against accidental-fire has been studied. Here case studies about high-rise buildings under fire condition, and statistical date will be examined. The risks resulting from fire including limited passages to escape, vertical beams, the huge numbers of occupants, and having some local limitations for doing fire operations determined. However deadly fires still occur in high-rise buildings in general, the procedures show that the number of fires, casualties and secondary costs are decreasing. This point is related to increasingly usage of fire sprinklers, resistant buildings against fire, smoke detector system. As regards the risks mentioned above the limitations and difficulties will be determined, and then the ways of protecting high-rise buildings against fire will be reviewed and studied. The highly effective ways for protecting against fire are the use of fire sprinklers, resistant buildings against fire, smoke detector system, and smoke management.

Duwe et al. (2005) [8] worked his research with subject "failure mode and effects analysis application to promote safety level" according to Spot's research (2003), and pointed out that this method is very efficient, and moreover used in industries, can be applied in medical and hygiene centers for improving patient's safety condition as well.

Yi Hui, Yukio Tamura, Qingshan Yang (2017) [9] in a research on the subject of 'analysis of interference effects on torsional moment between two high-rise buildings based on pressure and flow field measurement' studied. "In this study, the wind induced interference effects on the torsional load on two adjacent high-rise buildings are studied through wind tunnel experiment. Two different sectional shapes of high-rise buildings are studied and four kinds of arrangements are investigated. Results show that the mean torsion on a building when under interfered conditions can be tripled that for the isolated case. With the help of pressure measurement on the principal building and the flow field information around the buildings, the underlying mechanisms of some typical cases which exhibit strong interference effects are discussed. Results show that the intricate flow field around the principal building with the presence of an interfering building is the main case of the large torsion it experiences.

Eduardo E. C. Rodrigues, João P. C. Rodrigues, Luiz C. P. da Silva Filho (2017) [10] in an article with the subject 'comparative study of building fire safety regulations in different Brazilian states' studied the national fire safety regulations on structuring buildings. "This paper presents a 
comparative study among building fire safety regulations in different Brazilian states aiming at the development and adoption of a technical regulation at a national level. The results showed many differences in regulations on the mandatory requirements for fire protection systems; however, a similar technical base among state regulations showed that a Brazilian national-level fire safety regulation could be created.

\section{MODEL DESCRIPTION}

Since the main purpose of implementing of this research is the analyzing of effective factors for security and safety in highrise building against fire, it can be said this paper based on purpose is applied research. Applied research is a form of systematic inquiry that is implemented with applying of fundamental research's results for improving and promoting behaviors, methods, instruments, tools, products, structures, and applied patterns in human societies. The purpose of implementing an applied research is the development of applied knowledge on specific field [purpose]. In this paper, discourse level is abstract and cumulative too, but in specific field.

On the other hand, since in this paper we use the library studies [library science] and field research methods like questionnaire as well, it can be said this study based on nature and method is descriptive-survey research.

Since in this paper the industrial engineering approaches and operations research has been applied, so then our statistical population was comprised of senior managers in HSE.

For collecting data in this research, the interview and questionnaire tool were used.

Expert questionnaire for prioritizing main criteria is based on analytic hierarchy process (AHP) technique. This questionnaire was set on Saaty 9 point scale1.

With applying this model, the relative importance of criteria as a number based on AHP technique was estimated, and illustrated in Table 2. For pointing each value based on Saaty 9-point scale, as follows:

Table 2. Evaluation of factors [choices] in comparison with each other based on Saaty 9-point scale

\begin{tabular}{|c|c|c|}
\hline Value & $\begin{array}{c}\text { Compare } \mathbf{i} \text { to } \\
\mathbf{j}\end{array}$ & Comment \\
\hline 1 & $\begin{array}{c}\text { Equally } \\
\text { preferred }\end{array}$ & Choice $\mathrm{i}$ is equal to $\mathrm{j}$ \\
\hline 3 & $\begin{array}{c}\text { Moderately } \\
\text { refereed }\end{array}$ & $\begin{array}{c}\text { Choice } \mathrm{i} \text { has a little priority than } \\
\text { choice } \mathrm{j}\end{array}$ \\
\hline 5 & $\begin{array}{c}\text { Strongly } \\
\text { preferred }\end{array}$ & $\begin{array}{c}\text { Choice } \mathrm{i} \text { is more important than } \\
\text { choice } \mathrm{j}\end{array}$ \\
\hline 7 & $\begin{array}{c}\text { Very strongly } \\
\text { preferred }\end{array}$ & $\begin{array}{c}\text { Choice } \mathrm{i} \text { has much more priority } \\
\text { over choice } \mathrm{j}\end{array}$ \\
\hline 9 & $\begin{array}{c}\text { Extremely } \\
\text { preferred }\end{array}$ & $\begin{array}{c}\text { Choice } \mathrm{i} \text { is the first priority, and } \\
\text { is not comparable to choice } \mathrm{j}\end{array}$ \\
\hline $2,4,6$, & intermediate & $\begin{array}{c}\text { Shows intermediate values, i.e. } 8 \\
\text { represents importance more than } \\
7, \text { but less than } 9 \text { for choice } \mathrm{i}\end{array}$ \\
\hline
\end{tabular}

To simplicity it, the abbreviation forms in this paper were used as follows:

Table 3. Abbreviation forms

\begin{tabular}{|c|c|}
\hline Title & Abbreviations \\
\hline $\begin{array}{l}\text { Building structural } \\
\text { engineering }\end{array}$ & $\mathrm{C} 1$ \\
\hline $\begin{array}{c}\text { Fire alarm and firefighting } \\
\text { systems }\end{array}$ & $\mathrm{C} 2$ \\
\hline Safety design in building & $\mathrm{C} 3$ \\
\hline Occupants' behavioral skills & $\mathrm{C} 4$ \\
\hline materials used in building & S11 \\
\hline Building strength & S12 \\
\hline Access paths to the building & S13 \\
\hline Uses of building & S14 \\
\hline Portable extinguishers & S21 \\
\hline Fire warning & S22 \\
\hline Firefighting systems & S23 \\
\hline $\begin{array}{l}\text { Pumps and fire station } \\
\text { installations }\end{array}$ & S24 \\
\hline $\begin{array}{l}\text { Design of emergency } \\
\text { lighting }\end{array}$ & S31 \\
\hline Design of emergency exits & S32 \\
\hline $\begin{array}{c}\text { Design of locating lifts and } \\
\text { escalators }\end{array}$ & S33 \\
\hline Design of building stairwells & S34 \\
\hline $\begin{array}{c}\text { Design of suitable } \\
\text { ventilation systems in } \\
\text { building }\end{array}$ & S35 \\
\hline $\begin{array}{l}\text { Knowing the signs and } \\
\text { emergency exits }\end{array}$ & S41 \\
\hline $\begin{array}{c}\text { Knowing the emergency } \\
\text { evacuation }\end{array}$ & $\mathrm{S} 42$ \\
\hline $\begin{array}{l}\text { Knowing the way of } \\
\text { movement in smoke and } \\
\text { darkness }\end{array}$ & $\mathrm{S} 43$ \\
\hline $\begin{array}{l}\text { Knowing the way of using } \\
\text { firefighting equipment }\end{array}$ & S44 \\
\hline
\end{tabular}

Gender status, education, employment history [résumé] and the age of people participated in the study as follows:

Table 4. The frequency distribution of participants based on their sex

\begin{tabular}{|c|c|c|c|}
\hline Sex & Frequency & Percentage & $\begin{array}{c}\text { Cumulative } \\
\text { frequency } \\
\text { percentage }\end{array}$ \\
\hline Male & 24 & 92.3 & 92.3 \\
\hline Female & 2 & 7.7 & 100.0 \\
\hline Total & 26 & 100.0 & \\
\hline Male & 24 & 92.3 & 92.3 \\
\hline
\end{tabular}

\footnotetext{
${ }^{1}$ Thomas L. Saaty
} 


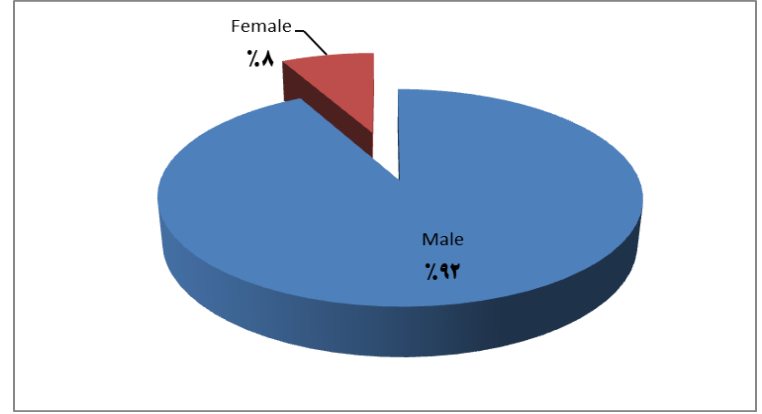

Fig 1. The frequency distribution of participants based on their sex

Table 5. The frequency distribution of participants based on their age

\begin{tabular}{|c|c|c|c|}
\hline Age & Frequency & $\begin{array}{c}\text { Percenta } \\
\text { ge }\end{array}$ & $\begin{array}{c}\text { Cumulative } \\
\text { frequency } \\
\text { percentage }\end{array}$ \\
\hline Under 30 & 3 & 11.5 & 11.5 \\
\hline $30-35$ & 8 & 30.8 & 42.3 \\
\hline $40-36$ & 7 & 26.9 & 69.2 \\
\hline 0ver 40 & 8 & 30.8 & \multirow{2}{*}{100} \\
\hline Total & 26 & 100 & \\
\hline
\end{tabular}

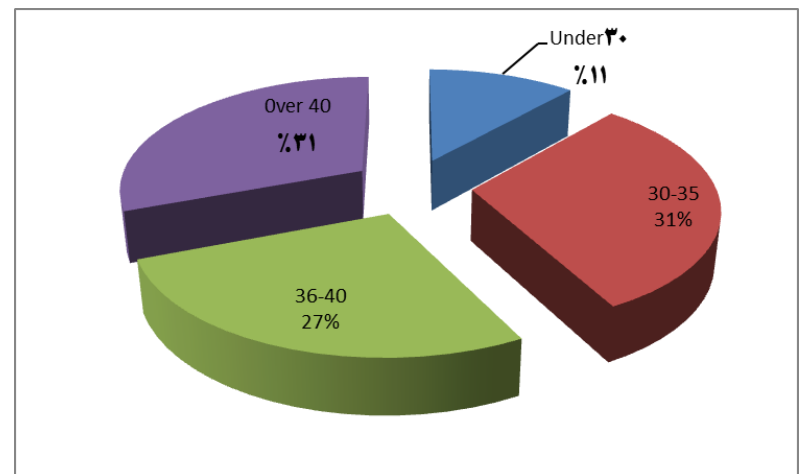

Fig 2. The frequency distribution of participants based on their age

For implementing AHP, first the main criteria according to the purpose have been compared in pairs. To do so, we use a group of experts, and with applying geometric mean technique and data normalization the values, the eigenvector calculated. The calculated numbers show the ratio of importance related to the main criteria. Calculations illustrated in Table 6.

Table 6. The frequency distribution of participants based on their employment history [résumé]

\begin{tabular}{|c|c|c|c|}
\hline $\begin{array}{c}\text { Employment } \\
\text { history }\end{array}$ & Frequency & Percentage & $\begin{array}{c}\text { Cumulative } \\
\text { frequency } \\
\text { percentage }\end{array}$ \\
\hline $\begin{array}{c}\text { Under } 10 \\
\text { years }\end{array}$ & 6 & 23.1 & 23.1 \\
\hline $10-15$ & 12 & 46.2 & 69.2 \\
\hline $16-20$ & 2 & 7.7 & 76.9 \\
\hline Over 20 years & 6 & 23.1 & \multirow{2}{*}{100.0} \\
\hline Total & 26 & 100.0 & \\
\hline
\end{tabular}

Based on calculated eigenvector:

The criterion of the occupants' behavioral skills with the normalized weight 0.538 is the first priority.

The criterion of the safety design in building with weight 0.3 has the second priority.

The criterion of the fire alarm and firefighting systems with normalized weight 0.110 has the third place.

The criterion of the building structural engineering with normalized weight 0.053 takes the fourth priority.

The inconsistency rate for the paired comparisons is $0 / 053$, that is less than $0 / 1$, so this comparison is reliable.

In the second step of AHP technique, we compared subcriterion of each criterion in pairs.

The calculations to determine the priority of the sub-criteria of the building structural engineering illustrated in Table 7.

Table 7. the frequency distribution of participants based on their education

\begin{tabular}{|c|c|c|c|}
\hline Education & Frequency & Percentage & $\begin{array}{c}\text { Cumulative } \\
\text { frequency } \\
\text { percentage }\end{array}$ \\
\hline $\begin{array}{c}\text { Associate } \\
\text { degree }\end{array}$ & 4 & 15.4 & 15.4 \\
\hline $\begin{array}{c}\text { Bachelor } \\
\text { degree }\end{array}$ & 12 & 46.2 & 61.5 \\
\hline $\begin{array}{c}\text { Master } \\
\text { degree }\end{array}$ & 10 & 38.5 & \multirow{2}{*}{100.0} \\
\hline Total & 26 & 100.0 & \\
\hline
\end{tabular}

For implementing AHP, first the main criteria according to the purpose have been compared in pairs. To do so, we use a group of experts, and with applying geometric mean technique and data normalization the values, the eigenvector calculated. The calculated numbers show the ratio of importance related to the main criteria. Calculations illustrated in Table 8 .

Table 8. prioritize the main effective criteria in high-rise buildings safety against fire

\begin{tabular}{|c|c|c|c|c|c|}
\hline & C1 & C2 & C3 & C4 & Eigenvector \\
\hline C1 & 1 & .245 & .196 & .172 & .053 \\
\hline C2 & 4.079 & 1 & .172 & .222 & .110 \\
\hline C3 & 5.111 & 100.0 & 1 & .291 & .300 \\
\hline C4 & 5.089 & 4.499 & 3.431 & 1 & .538 \\
\hline
\end{tabular}

Based on calculated eigenvector:

The criterion of the occupants' behavioral skills with the normalized weight 0.538 is the first priority.

The criterion of the safety design in building with weight 0.3 has the second priority.

The criterion of the fire alarm and firefighting systems with normalized weight 0.110 has the third place.

The criterion of the building structural engineering with normalized weight 0.053 takes the fourth priority.

The inconsistency rate for the paired comparisons is $0 / 053$, that is less than $0 / 1$, so this comparison is reliable.

In the second step of AHP technique, we compared subcriterion of each criterion in pairs. 
The calculations to determine the priority of the sub-criteria of the building structural engineering illustrated in Table 9.

Table 9. Determination of priority of the sub-criteria of the building structural engineering

\begin{tabular}{|l|c|c|c|c|c|}
\hline & S11 & S12 & S13 & S14 & Eigenvector \\
\hline S11 & 1 & .172 & .176 & .200 & .049 \\
\hline S12 & 5.830 & 1 & .200 & .234 & .126 \\
\hline S13 & 5.687 & 4.990 & 1 & .215 & .274 \\
\hline S14 & 4.990 & 4.267 & 4.658 & 1 & .551 \\
\hline
\end{tabular}

Based on calculated eigenvector:

The sub-criterion of uses of building with eigenvector 0.551 is the first priority.

The sub-criterion of the access paths to the building with eigenvector 0.274 takes the second place.

The sub-criterion of the building strength with eigenvector 0.126 is the first priority.

The sub-criterion of the materials used in building with eigenvector 0.049 has the second priority.

The inconsistency rate for the paired comparisons is 0.083 that is less than $0 / 1$, so this comparison is reliable.

The calculations to determine the priority of the sub-criteria of the fire alarm and firefighting systems illustrated in Table 10.

Table 10. Determination of priority of the sub-criteria of the fire alarm and firefighting systems

\begin{tabular}{|l|c|c|c|c|c|}
\hline & S21 & $\mathbf{S 2 2}$ & $\mathbf{S 2 3}$ & $\mathbf{S 2 4}$ & Eigenvector \\
\hline S21 & 1 & 0.149 & 0.155 & 0.200 & 0.046 \\
\hline S22 & 7.716 & 1 & .225 & 0.234 & 0.127 \\
\hline S23 & 6.467 & 4.453 & 1 & 0.215 & 0.274 \\
\hline S24 & 4.453 & 5.152 & 4.564 & 1 & 0.553 \\
\hline
\end{tabular}

Based on calculated eigenvector:

The first priority is the pumps and fire station installations, with the normalized weight 0.553 .

The second priority is the firefighting systems, with normalized weight 0.274 .

The third priority is the fire warning, with normalized weight 0.127 .

The last priority is the portable extinguishers with normalized weight 0.046 .

The inconsistency rate for the paired comparisons is 0.093 that is less than $0 / 1$, so this comparison is reliable.

The calculations to determine the priority of the sub-criteria of the safety design interior building illustrated in Table 11 .

Table 11. Determination of priority of the sub-criteria of the safety design interior building

\begin{tabular}{|l|c|l|l|l|l|c|}
\hline & S31 & S32 & S33 & S34 & S35 & Eigenvector \\
\hline S31 & 1 & 0.312 & 0.375 & 0.161 & 0.219 & 0.052 \\
\hline S32 & 3.205 & 1 & .528 & 0.280 & 0.368 & 0.109 \\
\hline
\end{tabular}

\begin{tabular}{|c|c|c|c|c|c|c|}
\hline S33 & 2.665 & 1.894 & 1 & 0.307 & 0.266 & 0.130 \\
\hline S34 & 6.214 & 3.570 & 3.262 & 1 & 0.333 & 0.293 \\
\hline S35 & 4.569 & 2.718 & 3.753 & 3.006 & 1 & 0.146 \\
\hline
\end{tabular}

Based on calculated eigenvector:

The first priority is the design of suitable ventilation systems in building, with the normalized weight 0416 .

The second priority is the design of building stairwells, with normalized weight 0.293 .

The third priority is the design of locating lifts and escalators, with normalized weight 0.130 .

The fourth priority is the design of emergency exits, with normalized weight 0.109 .

The last priority is the design of emergency lighting, with normalized weight 0.052 .

The inconsistency rate for the paired comparisons is 0.077 that is less than $0 / 1$, so this comparison is reliable.

Based on calculated eigenvector:

The first priority is the knowing the way of using firefighting equipment, with the normalized weight 0.512 .

The second priority is the knowing the way of movement in smoke and darkness, with normalized weight 0.282.

The third priority is the knowing the emergency evacuation, with normalized weight 0.151 .

The fourth priority is the knowing the signs and emergency exits, with normalized weight 0.055 .

The inconsistency rate for the paired comparisons is 0.08 that is less than $0 / 1$, so this comparison is reliable.

In this step, the ultimate priority of effective factors in highrise buildings' safety against fire is calculated. The results of comparison of the research's sub-criteria and related weights compose the matrix W2. To determine the ultimate priority with AHP technique, it is necessary to multiply the weight of elements [or factors] based on each criterion (W2) by the weight of main criteria (W1). When the weight of each main criterion (W1) and sub-criteria (W2) are available, we can calculate the weight of each factor. The results of calculations, and weights related to the factors showed in table 12 .

Table 12. Determination of ultimate priority of effective factors

\begin{tabular}{|c|c|c|c|c|}
\hline \multirow{2}{*}{$\begin{array}{c}\text { main } \\
\text { cluster }\end{array}$} & $\begin{array}{c}\text { cluster } \\
\text { weight }\end{array}$ & $\begin{array}{c}\text { sub- } \\
\text { criteria }\end{array}$ & $\begin{array}{c}\text { weight of } \\
\text { sub- } \\
\text { criteria }\end{array}$ & $\begin{array}{c}\text { ultimate } \\
\text { weight of } \\
\text { sub-criteria }\end{array}$ \\
\hline \multirow{3}{*}{ 1C } & 0.053 & $11 \mathrm{~S}$ & 0.049 & 0.003 \\
\cline { 2 - 5 } & & $12 \mathrm{~S}$ & 0.126 & 0.007 \\
\cline { 2 - 5 } & & $13 \mathrm{~S}$ & 0.274 & 0.014 \\
\hline \multirow{3}{*}{$2 \mathrm{C}$} & 0.110 & $21 \mathrm{~S}$ & 0.046 & 0.005 \\
\cline { 2 - 5 } & & $22 \mathrm{~S}$ & 0.127 & 0.014 \\
\cline { 2 - 5 } & & $23 \mathrm{~S}$ & 0.274 & 0.030 \\
\hline \multirow{2}{*}{$3 \mathrm{3C}$} & 0.300 & $31 \mathrm{~S}$ & 0.052 & 0.015 \\
\hline
\end{tabular}




\begin{tabular}{|c|c|c|c|c|}
\hline \multirow{4}{*}{} & & $32 \mathrm{~S}$ & 0.109 & 0.033 \\
\cline { 2 - 5 } & & $33 \mathrm{~S}$ & 0.130 & 0.039 \\
\cline { 2 - 5 } & & $34 \mathrm{~S}$ & 0.293 & 0.088 \\
\cline { 2 - 5 } & & $35 \mathrm{~S}$ & 0.416 & 0.125 \\
\hline \multirow{4}{*}{$4 \mathbf{C}$} & 0.538 & $41 \mathrm{~S}$ & 0.055 & 0.030 \\
\cline { 2 - 5 } & & $42 \mathrm{~S}$ & 0.151 & 0.081 \\
\cline { 2 - 5 } & & $43 \mathrm{~S}$ & 0.282 & 0.152 \\
\cline { 2 - 5 } & & $44 \mathrm{~S}$ & 0.512 & 0.275 \\
\hline
\end{tabular}

Therefore, based on results of the calculations, the ultimate weight of each factors have been calculated with AHP technique; then we have:

The first priority is the knowing the way of using firefighting equipment, with the normalized weight 0.275 .

The second priority is the knowing the way of movement in smoke and darkness, with normalized weight 0.152 .

The third priority is the design of suitable ventilation systems in building, with normalized weight 0.125 .

The fourth priority is the design of building stairwells, with normalized weight 0.088 .

The fifth priority is the knowing the emergency evacuation, with normalized weight 0.081 .

\section{CONCLUSION}

Given the importance of safety in high-rise buildings, it was tried in this paper to examine the effective factors on the safety of those buildings to determine the percentage of importance of the required factors, e.g. occupants' behavioral skills, safety design in building, etc.

The outcomes of prioritizing strategies for promoting the security and safety of high-rise buildings against fire showed that the criterion of occupants' behavioral skills with normalized weight 0.538 is the first priority, and the criterion of the safety design in building with normalized weight 0.3 takes the second place, then the fire alarm and firefighting systems with normalized weight 0.110 is the third priority, and ultimately, the criterion of the building structural engineering with normalized weight 0.053 have the fourth place.

The criterion of sub-criteria of the building structural engineering showed that sub-criterion of the uses of building with eigenvector is the first priority, and the access paths to the building with eigenvector 0.274 has the second place, then the building strength with eigenvector 0.126 is the third priority, and finally, the materials used in building with eigenvector takes the last place. Also the inconsistency rate for the paired comparisons is $0 / 083$.

Moreover, it showed in prioritizing sub-criteria of the fire alarm and firefighting systems that the highest priority is the pumps and fire station installations with normalized weight 0.553 , the firefighting systems with normalized weight 0.274 takes the second place, the third priority is the fire warning with normalized weight 0.127 , and then the portable extinguishers with normalized weight 0.046 has the last place. The inconsistency rate for the paired comparisons is $0 / 093$ too that shows it can be reliable.
Also, it showed in prioritizing sub-criteria of the safety design interior building that the highest priority is the design of suitable ventilation systems in building with normalized weight 0.416 , the design of building stairwells with normalized weight 0.293 takes the second place, then the third priority is the design of locating lifts and escalators with normalized weight 0.130 , and then the design of emergency exits with normalized weight 0.109 has the fourth place, and finally the design of emergency lighting with normalized weight 0.052 is the last priority. The inconsistency rate for the paired comparisons is $0 / 077$ that shows those comparisons can be reliable.

In addition, in determination of prioritizing the sub-criteria of the occupants' behavioral skills, it was clear that the highest priority is the knowing the way of using firefighting equipment with normalized weight 0.512 , the second place is for the knowing the way of movement in smoke and darkness with normalized weight 0.282 , and then the knowing the emergency evacuation with normalized weight 0.151 takes the third place, and finally the last priority is the knowing the signs and emergency exits with normalized weight 0.055 . The inconsistency rate for the paired comparisons is 0.08 too that shows it can be reliable.

In the next step, the ultimate priority of the strategies for promoting security and safety in high-rise buildings against fire was calculated, and the results of comparisons of research's sub-criteria and related weights illustrated in the Table ... . It shows that the highest priority is for sub-criteria of the knowing the way of using firefighting equipment with normalized weight 0.275 , the knowing the way of movement in smoke and darkness with normalized weight 0.152 takes the second place, then the third priority is for the design of suitable ventilation systems in building with normalized weight 0.125 , and finally the design of building stairwells with normalized weight 0.088 has the last place.

\section{Suggestions for future research}

In this study, we tried to analyze the all aspects and factors to identify and prioritize the promotion of security and safety in high-rise buildings against fire but since very little field studies in academic circles- especially domestic ones- in the field of safety in this kind of buildings have been done, then future researchers with expanding his studies by identifying and adjustment of factors can take the necessary action to improve the designed scale. These fields for case study and improving the next researches are recommended:

1. To promote the security and safety against the fire in an industry or another case study, this study can increase the scope of results, and as a means promote the future studies.

2. In this study, the AHP technique was used for ranking the criteria. To take effect on components to each other and relations between them, it is suggested that AHP technique to be used.

3. Another similar approach is the applying of grey relational analysis (GRA) that is less complicated. To determine the weight of criteria, it is suggested that grey relational analysis technique to be used.

4. It has been suggested that this research with the purpose "to identify the amount of impact of effective factors upon highrise buildings in other metropolis [big cities] that have the same building" to be implemented. 


\section{REFERENCES}

[1] Juan Chen, etc. Event-driven modeling of elevator assisted evacuation in ultra high-rise buildings Original Research Article Simulation Modelling Practice and Theory, Volume 74, May 2017, Pages 99-116

[2] P. Sharma, etc, (2014), "Evacuation Patterns in High-Rise Buildings", International Journal of Civil Engineering Research. ISSN 2278-3652 Volume 5, Number 3, pp. 255- 260.

[3] J. Koo, etc. A comparative study of evacuation strategies for people with disabilities in high - rise building evacuation, Expert Syst. Appl. 40 (2) (2013) 408-417.

[4] Z.M. Fang, etc. Experimental study on evacuation process in a stairwell of a high-rise building, Build. Environ. 47 (2012) 316-321.

[5] W.Z. Black, Smoke movement in elevator shafts during a high-rise structural fire, Fire Saf. J. 44 (2) (2009) 168182
[6] Mingchun Luo ,etc. (2006), "Evacuation Strategy for Super Highrise Buildings"

[7] W.K. Chow, (2006), "Fire Safety Provisions for Super-tall Buildings", International Journal on Architectural Science, Volume 7, Number 2, p.57-60.

[8] Duwe B, etc. "failure mode and effects analysis application to Critical care medicine". Critical Care Clinics 2005, 21 (1), 21-30.

[9] Yi Huia, etc . Analysis of interference effects on torsional moment between two high-rise buildings based on pressure and flow field measurement . Journal of Wind Engineering and Industrial Aerodynamics ,Volume 164, May 2017, Pages 54-68

[10] Eduardo E.C , etc . Comparative study of building fire safety regulations in different Brazilian states . Journal of Building Engineering • Volume 10, March 2017, Pages 102-108. 